\title{
MELIHAT DAN MEMBERI KESAKSIAN DALAM YOHANES 19:35
}

\author{
Fransiskus Saverius Marmidi* \\ Fakultas Filsafat Universitas Katolik Santo Thomas \\ Email: saverius_marmidi@ust.ac.íd
}

\begin{abstract}
Abstrak
Salah satu perbedaan antara Perjanjian Lama (PL) dan Perjanjian Baru (PB) adalah gambaran akan Allah. PL menekankan bahwa Allah itu tak terlihat, sedangkan PB menyatakan bahwa Allah telah menjadi manusia dalam diri Yesus Kristus yang dapat terlihat. Salah satu kata yang menggambarkan pengalaman akan Allah adalah "melihat." Kata tersebut tersebar baik dalam PL maupun PB. Khususnya dalam Injil Yohanes, digunakan empat kata yang

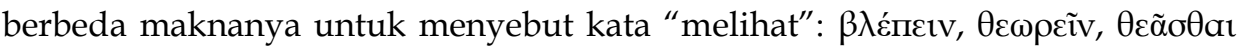
dan ó $\rho \tilde{v} v$. Kata "ó $\rho \tilde{\alpha} v$ " mengekspresikan penglihatan yang paling dalam di antara yang lain. Berdasarkan Yoh. 19:35, kata tersebut akan diteliti dengan melihat perbandingannya dengan teks lain, khususnya Yoh. 1:34, dimana berpangkal dari pengalaman melihat itu orang mampu memberikan kesaksian.
\end{abstract}

Kata-kata Kunci: Melihat, memberi kesaksian, murid yang terkasih, darah dan air.

Narasi Yoh. 19:31-37 tidak ditemukan pararelnya dalam Injil Sinoptik. Sejak jaman Patristik sampai abad ke-18, sebagaimana diteliti oleh Thomas More dalam bukunya: His Witness is True: John and His Interpreters, penafsiran Yoh. 19:31-37 selalu dihubungkan dengan 1Yoh 5:6-8 dengan mengangkat tema-tema besar yang kemudian memunculkan diskusi teologis seperti: kemanusiaan Kristus, sakramen baptis dan ekaristi, dan penyucian dan penebusan. Mulai abad ke-19, penafsiran atas teks tersebut lebih bersifat komentar biblis dan monografi. ${ }^{1}$ Perkembangan penafsiran ini mendorong saya untuk

${ }^{1}$ Sister Thomas More, CSJ, His Witness is True: John and His Interpreters (New York: Peter Lang Publishing, 1988). 
mengamati keberadaan ay.19:35 yang berbicara tentang seorang tokoh tanpa nama, "orang-yang-telah-melihat," yang memberikan kesaksian atas apa yang dilihatnya: lambung yang mengeluarkan darah dan air; dan kesaksiannya itu adalah benar. Dengan tidak berfokus pada mencari tahu siapakah saksi mata tersebut, tulisan ini hendak menelusuri "melihat" menjadi dasar untuk "memberikan kesaksian" dengan mendalami teks tersebut dan beberapa teks pararelnya dalam Injil Yohanes.

\section{Permasalahan Teks Yoh. 19:35}

Dalam manuskrip Old Latin Codex Palatinus (abad ke-5) dan Vulgate Codex Fuldensis (abad ke-6), ay.35 tidak ditulis dalam perikop. Dua manuskrip tersebut mengundang beberapa ahli untuk mempunyai argumen yang berbeda tentang keberadaan ay.35. Blass-Debrunner menyimpulkan bahwa keaslian ayat tersebut diragukan. ${ }^{2}$ Menanggapi itu, J.H. Bernard mengatakan bahwa kesimpulan Blass-Debrunner itu bertentangan. ${ }^{3}$ Sementara itu R.E. Brown dan R. Schnackenburg berpendapat bahwa, meski ay. 35 tidak ada dalam dua manuskrip di atas dan meski dianggap sebagai sisipan, namun keaslian ayat tersebut tidak diragukan lagi. ${ }^{4}$

Penelusuran teks asli ay.35 menemukan permasalah yang kedua, yaitu perbedaan penggunaan kata kerja "percaya" dalam: "supaya

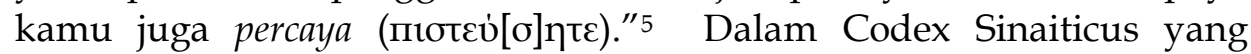
disimpan di perpustakaan London (abad ke-4) dan Codex Vaticanus

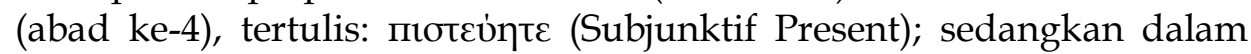
Codex Sinaiticus yang lain (abad ke-4) dan Codex Alexandrinus (abad

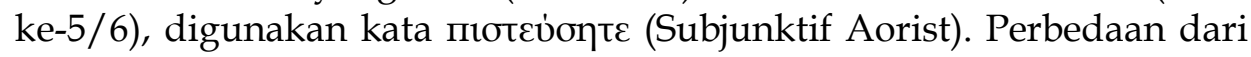

2 F. Blass dan A. Debrunner, A Greek grammar of the New Testament and other early Christian literature (Chicago: University of Chicago Press, 1961) hlm.152.

${ }^{3} \mathrm{~J}$. H. Bernard, A critical and exegetical commentary on the Gospel according to St. John (New York: C. Scribner' Sons, 1929) 2:649.

${ }^{4}$ R.E. Brown, S.S., The Gospel according to John (XIII-XXI): Introduction, translation, and notes (London: Yale University Press, 2008) hlm.936; R. Schnackenburg, The Gospel according to St John (New York: Crossroad, 1982) 3:287.

${ }^{5}$ Seperti yang ditulis dalam Nestle-Aland, Novum Testamentum Graece (Federal Republic of Germany: United Bible Societies, 199327): кaì ó $\dot{\varepsilon} \omega \rho a \kappa \grave{s}$

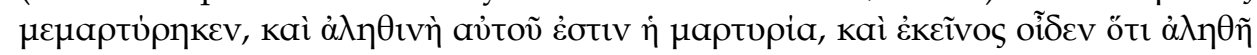

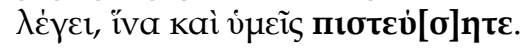


keduanya adalah soal aspek "berlangsung" atau "sesaat" suatu perbuatan dilakukan atau peristiwa terjadi; Present menjelaskan bahwa perbuatan atau peristiwa terjadi secara terus berlangsung, sedangkan Aorist menyatakan bahwa perbuatan atau peristiwa terjadi secara sesaat di masa lampau. ${ }^{6}$

Menghadapi permasalahan teks di atas, dengan merujuk catatan dari Metzger, Oniszczuk menyimpulkan bahwa bentuk Present mengandaikan iman yang terus berlangsung, sedangkan bentuk Aorist mengandaikan iman yang sedang lahir. Konsekwensinya, jika dipilih Present, penerima kabar gembira ("kamu") dalam ay.35 adalah orangorang kristen yang telah terlebih dahulu beriman yang dikuatkan untuk melanjutkan imannya; jika dipilih Aorist, para penerima kabar Injil dalam ayat ini adalah orang-orang bukan kristen atau mereka yang sedang mulai percaya. Bentuk mana yang lebih benar? Meski sebagian besar para komentar lebih memilih bentuk Present, teks Yunani menampilkan keduanya dengan memberi tanda kurung pada huruf $\sigma .{ }^{7}$ Justru karena mempunyai arti keduanya inilah, penafsiran teks semakin diperkaya.

\section{Penjelasan Linguistik-Sintatis Yoh. 19:35}

Terjemahan ini disesuaikan dengan teks Yunani: 8

Dan dia-yang-telah-melihat telah-memberi-kesaksian,

dan kesaksiannya adalah benar,

dan ia tahu

bahwa ia mengatakan kebenaran,

supaya kamu percaya.

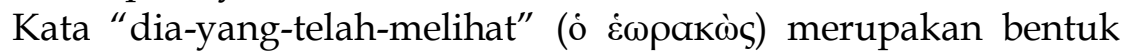
partisip perfekt aktif dari kata dasar "melihat" (óoũv) yang mempunyai fungsi sebagai kata benda yang menjelaskan seorang yang melihat apa yang terjadi di ayat sebelumnya. Kata kerja "telah-memberi-kesaksian"

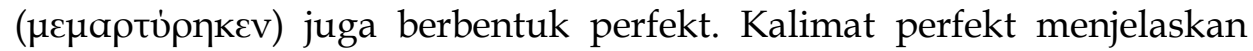

6 Lih. Filipo Serafini, Corso di Greco del Nuovo Testamento (Milano: Edizione San Paolo, 2003) hlm.199.

7 B.M. Metzger, A textual commentary on the Greek New Testament (London; New York: United Bible Societies, 1994) hlm.219; J. Oniszczuk, La Passione del Signore secondo Giovanni (Bologna: Edizione Dehoniano Bologna, 2011) hlm.199-200.

${ }^{8}$ Berdasarkan teks Nestle-Aland, op.cit. 
bahwa aksi sudah selesai terjadi di masa lampau, namun efeknya masih berlangsung sampai sekarang. ${ }^{9}$

Kata kerja "adalah" dan "mengatakan" mempunyai bentuk present, sedangkan "tahu" berbentuk perfekt namun mempunyai arti present. Hal yang mesti mendapat perhatian adalah kata penghubung "supaya" (iva) yang menegaskan bahwa anak kalimat setelahnya mempunyai arti akhir sebagai tujuan. ${ }^{10}$ Dengan ini dipahami bahwa tujuan kesaksian dari dia-yang-telah-melihat adalah "supaya kamu percaya." Namun penjelasan tersebut masih menyimpan pertanyaan: siapakah yang dimaksud dengan "kamu"? Siapakah atau apakah yang menjadi obyek dari "kamu percaya"?

\section{Melihat dan Memberi Kesaksian}

Injil Yohanes berbicara tentang "melihat" dengan menggunakan empat kata kerja berbeda yang mempunyai arti tersendiri, yaitu $\beta \lambda \varepsilon ́ n \varepsilon \imath v:$

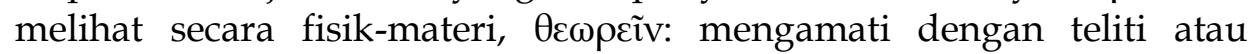
melihat dengan perhatian, $\theta \varepsilon \tilde{\alpha} \sigma \theta a \mathrm{a}$ merenungkan atau mengkontemplasi-kan, dan ó $\tilde{a} v$ : melihat dengan mata (arti dasar), melihat secara batin. ${ }^{11}$ Marilah kita lihat contoh penggunaan di bawah ini:

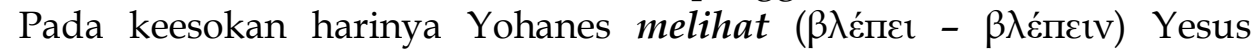

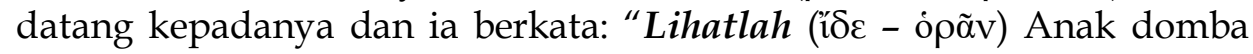
Allah, yang menghapus dosa dunia" (1:29; $\beta \lambda \varepsilon ́$ пєıv: lih. 1:36; bdk. 9:7.15.19.21.25.39.41; 13:22).

Dan sementara Ia di Yerusalem selama hari raya Paskah, banyak orang

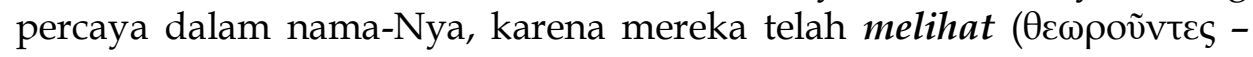
$\theta \varepsilon \omega \rho \varepsilon i ̃ v) ~ t a n d a-t a n d a$ yang diadakan-Nya (2:23; bdk. 6:19; 12:45; 16:10.16.17.19).

Firman itu telah menjadi manusia, dan diam di antara kita, dan kita

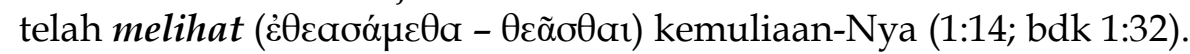

${ }^{9}$ F. Poggi, Corso Avanzato di Greco Neotestamentario (Milano: Edizione San Paolo, 2009) hlm.125.

${ }^{10}$ Ibid., hlm.174.

11 J. Kremer, "óó́ $\omega$ ” dalam: H.R. Balz dan G. Schneider, Exegetical Dictionary of the New Testament (Grand Rapids, Mich.: Eerdmans, 1990c1993) 2:527-529; M. Lee, Signore, Vogliamo Vedere Gesù: La conclusione dell'attività pubblica di Gesù secondo Gv 12,20-36 (Roma: Editrice Pontificia Università Gregoriana, 2005) hlm.71-76; Wilhelm Michaelis, "óoú $\omega$ ", dalam: G. Kittel, G. W. Bromiley dan G. Friedrich, Theological Dictionary of the New Testament (Grand Rapids, MI: Eerdmans, 1964-c1976) 5:329, menjelaskan bahwa kata óg் $\omega$, untuk רָָ dalam teks Ibrani, mempunyai karakter penglihatan kenabian. 


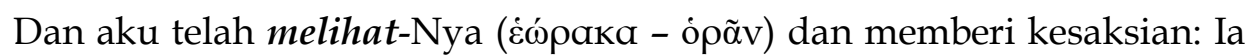
inilah Anak Allah. (1:34; bdk 1:36.39; 3:11.32; 8:38; 12:21; 19:35 ; 20:25).

Menurut Potterie, Injil Yohanes sengaja menggunakan empat kata kerja "melihat" dengan tujuan untuk menjelaskan perkembangan perjalanan dari "melihat", dari melihat secara fisik ke pengamatan, kemudian kontemplasi, dan yang terakhir adalah melihat secara batin. ${ }^{12}$ Hal tersebut bisa terlihat dalam narasi Yoh. 1:29-34 yang menceritakan perjalanan "melihat", yaitu dari melihat secara fisik ( $\beta \lambda \varepsilon ́ n \varepsilon ı v) ~(1: 29)$ ke melihat-merenungkan ( $\theta \varepsilon \tilde{\alpha} \sigma \theta a \imath)$ (1:32) dan akhirnya memuncak pada melihat secara batin (ópãv) (1:34).

Kata yang dipakai dalam 19:35 (dia-yang-telah-melihat) adalah

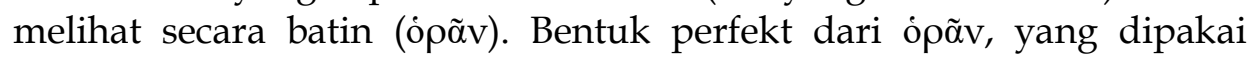
dalam ay.35, adalah tipe tulisan Yohanes, ${ }^{13}$ yang juga bisa ditemukan dalam beberapa ayat berikut.

Dalam beberapa teks Injil Yohanes, Yesus diceritakan sebagai orang yang melihat. Kata yang dipakai adalah melihat secara batin (ópõv). Dalam dialog dengan Nikodemus Ia berkata: “Aku berkata kepadamu, sesungguhnya kami berkata-kata tentang apa yang kami ketahui dan kami bersaksi tentang apa yang kami lihat, tetapi kamu tidak menerima kesaksian kami" (3:11). Bentuk yang sama juga ditemukan dalam ay. 3:32: "Ia memberi kesaksian tentang apa yang dilihat-Nya dan yang didengar-Nya" (bdk. 5:37; 8:38). Dari beberapa teks tersebut disimpulkan bahwa ketika kata "melihat" dihubungkan dengan kesaksian, isi kesaksian adalah tentang apa yang telah dilihat, sesuatu yang diperoleh dari pengalaman melihat, dan bukan dari sesuatu yang lain misalnya apa yang telah dipikirkan atau dirancang.

Kata "melihat" yang digunakan bersama dengan "memberi-kesaksian" ditemukan juga dalam pembaptisan Yesus ketika Yohanes Pembaptis berkata:

"Dan aku telah-melihat dan telah-memberi-kesaksian:

Ia inilah Anak Allah" (1:34).

Bandingkan:

"Dan dia-yang-telah-melihat telah-memberi-kesaksian" (19:35).

Kesaksian Yohanes Pembaptis adalah kesaksian dari seorang saksi mata. Ia bersaksi tentang Yesus dengan menegaskan identitas-Nya sebagai Anak Allah. Kesaksiannya ini berasal dari apa yang telah ia lihat dengan matanya sendiri: "Aku telah melihat Roh turun dari langit seperti

\footnotetext{
12 I. de la Potterie, "Volgeranno lo sguardo a colui che hanno trafitto: Sangue di Cristo e oblativa," CivCatt 3 (1986) 113.

${ }^{13}$ M. Lee, op.cit., hlm.73.
} 
merpati, dan Ia tinggal di atas-Nya" (1:32). ${ }^{14}$ Menurut Potterie, "melihat" dalam 1:34 adalah puncak perjalanan "melihat" dari Yohanes Pembaptis dalam perikop 1:29-34 yang mengalami proses dari melihat secara lahiriah ke spiritual-iman: "apa yang telah dilihat meninggalkan kesan yang tetap; penglihatan lahir menjadi gambaran batin, dan penglihatan fisik ditransformasikan ke dalam kontemplasi spiritual sebagai sebuah pandangan iman." 15

Kesaksian Yesus dan Yohanes Pembaptis berdasarkan pengalaman melihat (óõ̃v), namun keduanya mempunyai sifat yang berbeda: Yesus adalah orang yang menyatakan atau mewahyukan, sedangkan Yohanes Pembaptis adalah orang yang "menunjukkan". ${ }^{16}$ Sejak awal, kehadiran Yohanes Pembaptis adalah untuk "menunjukkan" dia yang mesti datang: "Ia datang sebagai saksi untuk memberi kesaksian tentang terang itu, supaya oleh dia semua orang menjadi percaya. Ia bukan terang itu, tetapi ia harus memberi kesaksian tentang terang itu" (1:7-8). Ia menunjukkan bahwa Yesus adalah Anak Domba Allah (1:29). Dalam kesaksian akan karya Allah yang diberikan kepadaNya, Yesus menegaskan bahwa Yohanes Pembaptis telah bersaksi tentang kebenaran (5:33).

Kata "melihat" (dalam arti ó $\rho \tilde{v}$ ) juga dikenakan pada tokoh lain: kepada dua murid pertama yang mengikuti-Nya, Yesus berkata: "'Marilah dan kamu akan melihatnya.' Merekapun datang dan melihat" (1:39); dia-yang-telah-melihat (19:35); seorang murid ketika sampai di kubur Yesus "melihat dan percaya" (20:8); Maria Magdalena ketika membawa kabar kebangkitan kepada para murid, "Aku telah melihat Tuhan" (20:18); para murid yang sedang berkumpul di dekat danau Tiberias memberi kesaksian kepada Tomas, "Kami telah melihat Tuhan" (20:25); kata Yesus kepada Tomas yang sebelumnya tidak percaya akan kebangkitan-Nya, "Karena engkau telah melihat Aku, maka engkau hlm.295.

${ }^{14}$ Lih. R. Schnackenburg, op.cit., 1:305; J. H. Bernard, op.cit., 1:52.

${ }^{15}$ I. de la Potterie, Studi di Cristologia Giovannea (Genova: Marietti, 1986)

${ }^{16}$ L. Coenen, "Testimonianza - $\mu \alpha \rho \tau$ ropia," dalam: L. Coenen dan E. Beyreuther, Dizionario dei concetti biblici del Nuovo Testamento (Bologna: Edizione Dehoniano Bologna, 1989) hlm.1857-1866, menjelaskan bahwa subyek yang memberikan kesaksian dalam Injil Yohanes dapat dibedakan menjadi tiga sifat yang berbeda: Penunjuk (Yohanes Pembaptis dan Kitab Suci), Yesus dan para murid; Dalam mengomentari Yoh. 3:11, R. Schnackenburg, op.cit., 1:375 berpendapat: "Jesus would then be designating himself as the heavenly revealer in an absolute and exclusive sense." 
percaya. Berbahagialah mereka yang tidak melihat, namun percaya" (20:29).

Berbeda dengan yang lain, "melihat" dari saksi mata di bawah salib (19:35) mesti diletakkan dalam konteks cerita, bahwa apa yang telah dilihat adalah lambung Yesus yang tertikam dan yang mengeluarkan air dan darah (19:34), dan dia-yang-telah-melihat peristiwa tersebut memberikan kesaksian. Sekali lagi, "melihat" dirumuskan dalam bentuk partisip perfekt yang berfungsi sebagai kata benda "dia-yang-telah-melihat". Bentuk ini hendak menekankan pengalaman yang diperoleh dari melihat yang dimiliki oleh orang yang telah melihat dan yang terus menyimpan-membatinkan penglihatan itu. ${ }^{17}$ Atau, sebagaimana yang ditegaskan oleh Brown, bentuk kata tersebut hendak mengungkapkan pengalaman batin dan kontemplasi iman dari saksi mata terhadap kematian Yesus, dan saksi mata tersebut membawa kesaksian yang benar "supaya kamu percaya." 18

Menurut Injil Yohanes, kematian Yesus di atas salib merupakan saat peninggian-kemuliaan-Nya (lih. 3:14-15; 8:28; 12:31-32) dan sebagai tindakan pernyataan cinta Allah bagi Dunia (lih. 3:16). Sementara itu air dan darah dalam 19:34 yang dilihat oleh dia-yang-telah-melihat dan ia membuat kesaksian atasnya, mesti dipahami dalam arti fisik dan simbolis. Para ahli mempunyai penafsiran yang bervariasi. Dodd menegaskan bahwa darah dan air dari lambung yang tertikam adalah simbol kehidupan yang mengalir dari Yesus yang disalibkan. ${ }^{19}$ Menurut Brown, air adalah lambang Roh Kudus, sementara darah menunjukkan bahwa Yesus wafat. ${ }^{20}$ Sedangkan menurut Carson, darah yang keluar setelah kematian Yesus adalah sumber kehidupan kekal bagi orang yang percaya (6:53-54) dan menyucikan dosa-dosa (1Yoh. 1:7), sedangkan air adalah lambang penyucian (Yoh. 3:5), kehidupan (4:14) dan Roh Kudus $(7: 38-39) .{ }^{21}$

Untuk memahami beberapa argumen tersebut, mengambil penafsiran Potterie, penafsiran air mesti dihubungkan dengan percakapan Yesus dengan wanita Samaria (4:10-14) yang berbicara

17 Lih. I. de la Potterie, "Volgeranno lo sguardo," hlm.113.

18 R.E. Brown, S.S., La morte del Messia, Un commentario ai Racconti della Passione nei quattro vangeli (Brescia: Editrice Queriniana, 1999) hlm. 1336.

19 C.H. Dodd, The Interpretation of the Fourth Gospel (Cambridge: Cambridge University Press, 1953) hlm.428; bdk. F.J. Moloney, The Gospel of John (Collegeville, Minnesota: The Liturgical Press, 1998) hlm.509.

${ }^{20}$ R.E. Brown, S.S., The Gospel (XIII-XXI), hlm.950.

${ }^{21}$ D.A. Carson, The Gospel according to John (Grand Rapids, Mich.: W.B. Eerdmans, 1991) hlm.624. 
tentang haus dan air kehidupan, dan pernyataan diri Yesus pada puncak perayaan yang berbicara tentang aliran-aliran air hidup yang mengalir dari hatinya dan yang adalah simbol Roh Kudus (7:37-39). Lebih dari itu, sebelum wafat Yesus berkata: "Aku haus" (19:28), lalu Ia

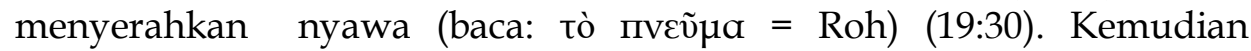
mengalirlah air dari lambung-Nya (19:34). Sedangkan arti darah mesti dihubungkan dengan perkataan Yesus yang terakhir sebelum kematianNya: "Sudah selesai" (19:30) dalam mana kematian dihubungkan dengan simbol darah. Darah yang mengalir dari lambung-Nya bukan hanya tanda material yang menjelaskan bahwa Ia sudah wafat, namun lebih dari itu adalah sumber kehidupan. ${ }^{22}$

Dari penjelasan di atas, ditemukan pararel bahwa, dalam penafsiran simbolis, apa yang dilihat oleh dia-yang-telah-melihat melebihi apa yang dilihat oleh Yohanes Pembaptis dalam pembaptisan Yesus. Obyek yang dilihat oleh Yohanes Pembaptis dan dari penglihatan itu ia memberikan kesaksian adalah Roh Kudus yang turun di atas Yesus; sementara obyek yang dilihat oleh dia-yang-telah-melihat di bawah salib adalah air dan darah yang mengalir dari lambung Yesus yang tertikam yang bukan hanya melambangkan Roh Kudus yang keluar dari Yesus, namun juga melambangkan pemberian hidup Yesus bagi dunia. Yohanes Pembaptis melihat Roh Kudus turun atas Yesus pada saat Yesus memulai aktivitas publik-Nya, sedangkan dia-yangtelah-melihat melihat air dan darah dari lambung tertikam pada saat kepenuhan (baca: "sudah selesai")-nya karya Yesus dan saat peninggian-Nya.

\section{Siapakah dia-yang-telah-melihat itu?}

Dalam perikop Yoh. 19:31-37, identitas dia-yang-telah-melihat adalah anonim, tanpa nama. Siapakah saksi mata ini? Apakah ia penulis Injil atau seorang tokoh lain?

Memperhatikan cerita sebelumnya dalam 19:25-27, ada beberapa orang yang berdiri di dekat salib Yesus, yaitu Maria Ibu Yesus, saudara Maria, isteri Klopas, Maria Magdalena, dan murid yang dikasihi-Nya. Meski belum begitu jelas, dapat dipastikan bahwa saksi mata itu adalah seorang dari mereka. Untuk mengkarifikasi lebih jauh identitasnya, baiklah diperhatikan dua kutipan di bawah ini:

22 Lih. I. de la Potterie, Studi di Cristologia, hlm.165-190. 
Dan dia-yang-telah-melihat telah-memberi-kesaksian, dan kesaksiannya adalah benar, dan ia tahu bahwa ia mengatakan kebenaran, supaya kamu percaya (19:35).

Dia adalah murid yang-memberi-kesaksian tentang semuanya ini dan yang telah menuliskannya dan kita tahu, bahwa kesaksiannya itu benar (21:24).

Dalam 21:24, yang dimaksud dengan murid yang-memberi-kesaksian adalah murid yang dikasihi Yesus (21:20-23). Dengan membandingkan penggunaan kata dalam kalimat di dua kutipan di atas: "memberikesaksian", "tahu" dan "kesaksiannya adalah benar," beberapa ahli berpendapat bahwa identitas dia-yang-telah-melihat dalam 19:35 adalah murid yang terkasih, dan tidak ada kemungkinan untuk menunjuk tokoh lain selain murid itu. ${ }^{23}$

Dalam Injil Yohanes, murid yang terkasih muncul beberapa kali mulai dalam cerita pembasuhan kaki dan setelahnya (13:23; 19:26; 21:7.20). ${ }^{24}$ Murid ini selalu dihadirkan secara anonim dan tanpa nama dalam cerita, namun digambarkan relasinya dengan Yesus. Dengan ini Injil Yohanes seakan menunjukkan bahwa identitas murid tersebut terletak bukan pada namanya tetapi pada relasinya dengan Yesus. Sebagai perbandingan, relasinya dengan Yesus dapat digambarkan seperti Yesus yang duduk di pangkuan Bapa sebagaimana pararel dua ayat di bawah ini dengan kata "dada/pangkuan" (кóৗпоৎ) yang samasama dipakai sebagai kata kunci:

Tidak seorangpun yang pernah melihat Allah; tetapi Anak Tunggal

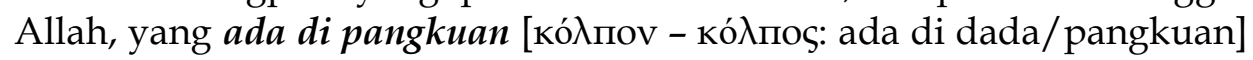
Bapa, Dialah yang menyatakan-Nya (1:18)

Seorang di antara murid Yesus, yaitu murid yang dikasihi-Nya,

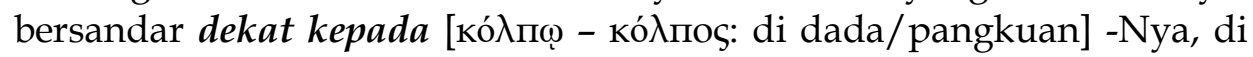
sebelah kanan-Nya (13:23).

Dalam tulisan Yunani klasik, kata кóגпо diartikan sebagai kandungan/rahim seorang ibu atau kasih keibuan. Septuaginta menggunakan kata tersebut untuk menggambarkan relasi pernikahan (Ul. 13:7; 28:54) dimana isteri menjadi milik suami dan memberikan diri padanya (Kej. 16:5), dan suami menjadi milik isteri (Ul. 28:56). ${ }^{25}$ Murid yang terkasih digambarkan bersandar di dada Yesus, dalam arti bahwa ia mempunyai relasi kasih yang intim dan unik dengan Yesus. Meski

23 J. H. Bernard, op.cit., 2:649; R.E. Brown, S.S., op.cit., hlm.936; R. Schnackenburg, op.cit., 3:290-291; F.J. Moloney, op.cit., 509.

${ }^{24}$ Identitasnya sebagai: murid yang dikasihi (Yesus).

25 Rudolf Meyer, "кóภпоs" dalam: G. Kittel, G. W. Bromiley dan G. Friedrich, op.cit., 3:824. 
mengandung arti afektif, ${ }^{26}$ relasi tersebut memampukan murid yang terkasih menjadi penyingkap rahasia hidup Yesus sebagaimana Yesus menyatakan rahasia Bapa. Dalam cerita Yoh. 13:21-30, setelah pembasuhan kaki, Yesus mengatakan bahwa ada orang yang akan menyerahkan-Nya. Para murid tidak mengetahuinya, juga Petrus. Untuk mengetahui siapa murid yang akan menyerahkan Yesus, Petrus meminta bantuan kepada murid yang terkasih untuk menanyakannya pada Yesus, dan kata murid itu: "Tuhan, siapakah itu?" Selanjutnya tidak diceritakan bahwa murid itu memberitahukan rahasia tersebut kepada para murid yang lain. Hanya dia yang tahu rahasia itu!27

Dengan menganalisa identitas dia-yang-telah-melihat (19:35) dan relasinya yang paling dekat dengan Yesus bila dibandingkan dengan murid yang lain, di sini mau ditekankan kekhususan saksi mata di bawah salib. Di antara para murid, ia yang paling mengetahui rahasia hidup Yesus. Dalam kerangka ini, apa yang dilihatnya, yaitu air dan darah dari lambung Yesus, adalah rahasia yang ia alami; dan kesaksiannya akan pengalaman melihat itu bisa disandingkan dengan upaya menyatakan rahasia Yesus "supaya kamu percaya."

\section{Kamu dalam "supaya kamu percaya"}

Tidak diragukan lagi bahwa yang dimaksud dengan "kamu" adalah pembaca kepada siapa Injil ditulis. Dalam mendiskusikan bagaimana teks Kitab Suci semestinya dipelajari dan dipahami oleh pembaca, Moloney mengajukan pertanyaan demikian: "how does the reader in the text who emerges as this ancient story of Jesus unfolds speak to the knowledge and experience of the twenty-first century Christian reader of the text?" 28 Pertanyaan tersebut mendorong untuk menyebut adanya pembaca di masa lampau dan masa sekarang. Masalah teks Yoh. 19:35 tentang "percaya" yang terbuka akan penafsiran ganda, bisa membuka jalan untuk menelusuri siapa "kamu" dari pembaca Injil.

Dihubungkan dengan 20:31, "kamu" dalam 19:35 adalah kelompok pembaca atau umat yang menjadi tujuan Injil ditulis. R.

${ }^{26}$ Lih. R.E. Brown, S.S., The Gospel (I-XII), hlm.17.

27 Dalam kisah penampakan Yesus kepada para murid-Nya di pantai danau Tiberias, ketika para murid menangkap ikan dan Yesus berdiri di pantai, murid yang pertamakali mengenal bahwa yang berdiri itu adalah Yesus Tuhan adalah murid yang terkasih dengan berkata kepada Petrus: "Itu Tuhan" (Yoh. 21:7).

${ }^{28}$ F.J. Moloney, op.cit., hlm.18. 
Bauckham mempelajari bahwa dengan mengamati istilah-istilah dan simbol-simbol yang digunakan dalam Injil, bahasa yang digunakan pada jaman Injil ditulis belum lazim dan belum dikenal baik oleh pembaca. ${ }^{29}$ Sementara itu dalam observasinya, J.L. Martyn menegaskan bahwa Injil Yohanes menceritakan tidak hanya kisah Yesus, namun juga kisah komunitas kristiani yang dalam konflik dengan orang-orang Yahudi karena iman mereka akan Yesus Mesias, dikeluarkan dari sinagoga atau komunitas orang-orang Yahudi (lih. 9:22; 12:42; 16:2). ${ }^{30}$ Dalam situasi umat yang sedang mulai percaya dan diliputi pertentangan tersebut, pembaca diajak untuk mempunyai kedewasaan iman dalam Yesus Kristus. Pembaca mesti mengenal bahwa kematian Yesus mempunyai makna keselamatan dan merupakan rahmat bagi kehidupan yang dilambangkan dengan keluarnya darah dan air dari lambung-Nya.

Teks Yoh. 19:35, juga seluruh Injil, ditujukan untuk mereka yang sudah percaya dan masih terus melanjutkan imannya, termasuk orangorang kristiani di jaman sekarang. Mereka dikuatkan untuk melanjutkan iman mereka dengan melihat kematian Yesus. Darah yang keluar dari lambung Yesus yang tertikam saat wafat-Nya adalah darah yang mesti diminum: "Barangsiapa makan daging-Ku dan minum darah-Ku, ia mempunyai hidup yang kekal" (6:54). Sebagaimana ditafsirkan oleh para bapa Gereja, dari kematian-Nya lahirlah kehidupan sakramental, Baptis dan Ekaristi. Orang-orang kristiani sebagai Gereja menerima rahmat dari Yesus yang tersalib yaitu darah dan air yang adalah simbol dari keselamatan, seperti yang dikatakan oleh Santo Agustinus: "Darah ditumpahkan demi pengampunan dosa-dosa dan air menawarkan minuman keselamatan dan penyucian" (Agostino, In Joh. CXX,2).

\section{Penutup}

Dinamika teks Yoh 19:35 menggambarkan perjalanan iman seorang saksi mata: dari "melihat" ke "memberikan kesaksian" dengan tujuan "supaya kamu percaya." Saksi mata tersebut diidentifikasikan sebagai murid yang terksih, dan Injil Yohanes menyebut lebih pada relasinya dengan Yesus ketimbang namanya. Relasinya dengan Yesus berbeda dengan Yohanes Pembaptis atau bahkan para murid yang lain. Dialah yang telah melihat peristiwa mengucurnya darah dan air dari

\footnotetext{
${ }^{29}$ R. Bauckham, The Testimony of the Beloved Disciples. Narrative, History, and Theology in the Gospel of John (Michigan: Bake Academic, 2007) hlm.119.

30 J.L. Martyn, History and Theology in the Fourth Gospel (Nashville: Westminster John Knox Press, 1983) hlm.15.
} 
lambung Yesus yang tertikam, dan dari pengalaman melihat ini, ia memberi kesaksian. Seakan ia adalah saksi mata yang menafsirkan kematian Yesus sebagai pemenuhan dari apa yang telah dikatakan Yohanes Pembaptis: "Lihatlah Anak domba Allah, yang menghapus dosa dunia" (1:29), dan apa yang telah Yesus sendiri katakan: "Dan sama seperti Musa meninggikan ular di padang gurun, demikian juga Anak Manusia harus ditinggikan" (3:14; bdk. 8:28; 12:32).

\section{DAFTAR PUSTAKA}

Bauckham, R. The Testimony of the Beloved Disciples. Narrative, History, and Theology in the Gospel of John. Michigan: Bake Academic, 2007.

Bernard, J.H. A critical and exegetical commentary on the Gospel according to St. John. 2 vol. New York: C. Scribner' Sons, 1929.

Blass, F. - Debrunner, A. A Greek grammar of the New Testament and other early Christian literature. Chicago: University of Chicago Press, 1961.

Brown, S.S., R.E. The Gospel according to John (I-XXI): Introduction, translation, and notes. 2 vol. London: Yale University Press, 1974-2008.

Passione nei quattro vangeli. Brescia: Editrice Queriniana, 1999.

Carson, D.A. The Gospel according to John. Grand Rapids, Mich.: W.B. Eerdmans, 1991.

Coenen, L., "Testimonianza - $\mu$ aptupia," dalam Coenen, L. Beyreuther, E. Theologisches Begriffslexikon zum NT. Wuppertal 1970; terj. Italia. Dizionario dei concetti biblici del Nuovo Testamento. Bologna: Edizione Dehoniano Bologna, 1989, 1857-1866.

Dodd, C.H. The Interpretation of the Fourth Gospel. Cambridge: Cambridge University Press, 1953.

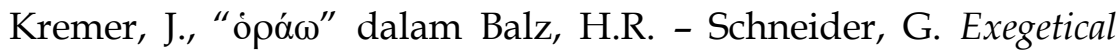
Dictionary of the New Testament. 3 vol. Grand Rapids, Mich.: Eerdmans, 1990-1993, 2:634-641.

Lee, M. Signore, Vogliamo Vedere Gesù: La conclusione dell'attività 
Fransiskus Saverius Marmidi, Melihat dan Memberi Kesaksian

pubblica di Gesù secondo Gv 12,20-36. Roma: Editrice Pontificia Università Gregoriana, 2005.

Martyn, J.L. History and Theology in the Fourth Gospel. Nashville: Westminster John Knox Press, 1983.

Metzger, B.M. A textual commentary on the Greek New Testament. London; New York: United Bible Societies, 1994.

Meyer, Rudolf, "ко́入поs" dalam Kittel, G. (ed.). Theological Dictionary of the New Testament. 10 vol. Grand Rapids, MI: Eerdmans, 1964-1976, 3:824-826.

Michaelis, Wilhelm, "ópó $\omega$ ", dalam Kittel, G. (ed.). Theological Dictionary of the New Testament. 10 vol. Grand Rapids, MI: Eerdmans, 1964-1976, 8:885-1035.

Moloney, F.J. The Gospel of John. Sacra Pagina. Collegeville, Minnesota: The Liturgical Press, 1998.

More, CSJ, Thomas. His Witness is True: John and His Interpreters. New York: Peter Lang Publishing, 1988.

Nestle-Aland. Novum Testamentum Graece. Federal Republic of Germany: United Bible Societies, $1993^{27}$.

Oniszczuk, J. La Passione del Signore secondo Giovanni. Bologna: Edizione Dehoniano Bologna, 2011.

Poggi, F. Corso Avanzato di Greco Neotestamentario. Milano: Edizione San Paolo, 2009.

de la Potterie, I. Studi di Cristologia Giovannea. Genova: Marietti, 1986.

--------, "Volgeranno lo sguardo a colui che hanno trafitto: Sangue di Cristo e oblativa," dalam Civiltà Cattolica. (Roma), no.3, 1986.

Rodrigues de Sousa, M.J. Para que também vòs acrediteis. Estudo exegético-teologico de Jo 19,31-37. Roma: Editrice Pontificia Università Gregoriana, 2009.

Schnackenburg, R. The Gospel according to St John. 3 vol. New York: Crossroad, 1982.

Serafini, Filipo. Corso di Greco del Nuovo Testamento. Milano: Edizione San Paolo, 2003. 